\title{
Harvesting of salep orchids in north-western Greece continues to threaten natural populations
}

\author{
Anna Kreziou, Hugo de Boer and Barbara Gravendeel
}

\begin{abstract}
In several eastern Mediterranean countries orchids are collected from the wild for the production of salep, a beverage made of dried orchid tubers. The drivers of this collection and trade have changed over time. We investigated which genera and species are harvested for salep production, whether any cultivation takes place, the chain of commercialization, and the economic value of tuber collection. Fieldwork and interviews in north-western Greece included 25 collectors and street vendors, the owners of two companies, and one herbal shop. The results show that several orchid species are traded for the production of salep, and none are cultivated. Tubers collected in Greece, Albania and Turkey are sold in northern Greece for EUR 55-150 per kg on average. Recent catalysts such as the increasing demand for traditional, organic and alternative foodstuffs, and the 2009 economic downturn, have led to a revival of salep consumption, with an increasing number of salep harvesters from Greece and Albania scouring the mountains for harvestable tubers, using unsustainable harvesting practices.
\end{abstract}

Keywords CITES, medicinal plants, northern Greece, orchids, salep, sustainability, traditional ecological knowledge (TEK)

$\mathrm{O}$ rchids have a history of use in many cultures. They are a significant source of nourishment, and many species are used as aphrodisiacs (Bulpitt, 2005). In Tanzania, Zambia and Malawi, for example, tubers of terrestrial orchids are used in making a staple food called chikanda (Davenport \& Ndangalasi, 2003; Veldman et al., 2014). In the eastern Mediterranean, dried tubers of terrestrial orchids are known as salep, which also refers to ground tuber powder and the beverage made from this powder. Salep is used in ice-cream production, confectionery and beverages (Kasparek \& Grimm, 1999; Tamer et al., 2006). In Greece it

\section{AnNa KrezIou Argonafton 30, Thessaloniki, Greece}

Hugo de Boer ${ }^{*} \dagger$ and Barbara Gravendeel $\ddagger$ (Corresponding author) Naturalis Biodiversity Center, Leiden, The Netherlands

E-mail barbara.gravendeel@naturalis.nl

*Also at: Uppsala University, Uppsala, Sweden

$\dagger$ Also at: The Natural History Museum, University of Oslo, Norway

¥Also at: University of Applied Sciences Leiden, Leiden, The Netherlands

Received 19 January 2015. Revision requested 6 February 2015.

Accepted 12 February 2015. First published online 28 April 2015 is used mainly in a beverage known as salepi, which is sold in local markets and is popular as a warming drink during the winter (Starin, 2012). Before the introduction of coffee the salep beverage was a common drink in Europe (Landerer, 1850), but now it is consumed mainly in Greece (Starin, 2012) and Turkey (Sezik, 2002; Bulpitt, 2005).

Although synthetic alternatives to salep exist, such as cereal starch or carboxymethyl-cellulose (Tamer et al., 2006), the demand for orchid tubers remains high among those seeking authentic salep (Kasparek \& Grimm, 1999). Sezik (2006) estimated the annual harvest of genuine salep in Turkey to be as much as $30 \mathrm{t}$. To produce $1 \mathrm{~kg}$ of salep 1,000-4,000 tubers, each representing an individual plant, are required (Kasparek \& Grimm, 1999), and this suggests that 30-120 million plants are harvested annually in Turkey alone. In Iran, it is estimated that 5.5-6.1 million orchids are harvested annually, mainly for export to Turkey (Ghorbani et al., 2014a).

Orchid use in Greece dates back several millennia. In Historia Plantarum Theophrastus (372-286 BC) attributed medicinal properties to orchid species, and in De Materia Medica Dioscorides (50-70 AD) ascribed healing properties to two terrestrial orchids based on the resemblance of their tubers to testicles (Berliocchi, 1996; Bulpitt, 2005). In the 180os salep harvesting by Albanians and Aromanians (Vlachs) was widespread in Greece, and salepi was a winter staple among the working classes (Landerer, 1850). Modern uses of orchids, and salepi in particular, are still based on these ancient traditions.

In Greece the Orchidaceae family is represented by c. 193-212 taxa, depending on species concepts (Delforge, 2006; Petrou et al., 2011), and all orchids are protected under presidential decree 67/1981, national law 1335/1983, and national law 2005/1992, which enacts CITES.

We conducted structured interviews with harvesters, traders and users of orchid tubers in 10 villages in Grevena, Ioannina, Kozani and Thessaloniki prefectures, in the Epirus, West and Central Macedonia regions of Greece (Fig. 1). Local informants, eight women and 17 men aged $40-80$ years, were interviewed in the spring and summer of 2013 and 2014. In addition, field visits were made to the collection areas to record species diversity, abundance and harvesting procedures. Relevant literature and herbarium specimens of local orchids were consulted, and all information pertaining to traditional use of salep was recorded (Lazarides, 1986; 


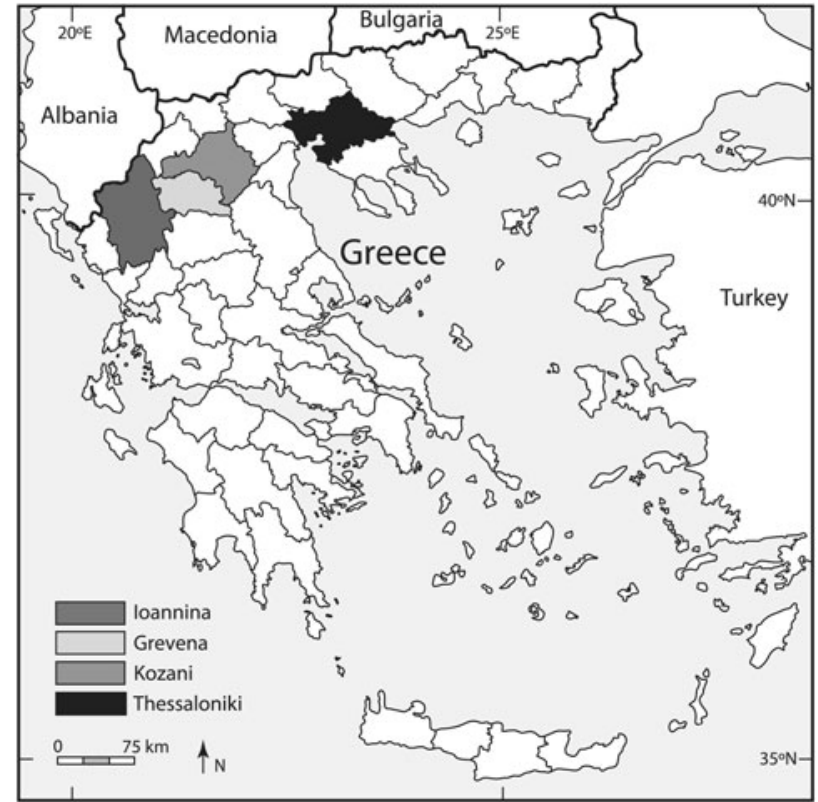

FIG. 1 Ioannina, Grevena, Kozani and Thessaloniki prefectures in Greece, where interviews were conducted with harvesters, traders and users of orchid tubers.

Vokou et al., 1993; Kasparek \& Grimm, 1999; Tamer et al., 2006; Petrou et al., 2011).

We found that several species in the genera Anacamptis, Dactylorhiza and Orchis are collected for the production of salep (Table 1). Various stages in salep harvesting, processing and consumption are shown in Plate 1. At the time of harvesting, each plant has one old tuber, which has already yielded a flowering plant, and one new perennating tuber, which will yield the next year's plant. The old tuber is scabrous and wrinkled, whereas the new one is fleshy and plump. In most cases collectors harvest the tubers when the plant has finished flowering but before it sets seed, which limits regeneration in wild populations. All informants reported collecting the young fresh tuber only; mostly, the old shrunken tuber is discarded. Three of the informants also reported that a trade in orchids takes place across the border with Albania. All collectors claimed not to be aware that collecting is forbidden, but most expressed interest in maintaining plant populations because they realized that overharvesting can be detrimental.

In the past, orchid tubers were collected in northern Greece to make salep beverages and a gelatin for porridge, and these were a staple consumed by the working classes (Landerer, 1850). Nowadays, the most popular form of salep is the hot beverage, and the main medicinal uses are to soothe the throat, as a remedy for colds and coughing, and to ease stomach ache and intestinal cramps. In Thessaloniki patisseries prepare dondurma ice cream using powdered salep, and several pharmacies sell a commercial brand of salep-based lozenges and syrup.
TABLE 1 Orchid species collected in northern Greece for salep, with past and present reported uses.

\begin{tabular}{|c|c|c|}
\hline \multirow[b]{2}{*}{ Species } & \multicolumn{2}{|l|}{ Reported use } \\
\hline & $1850-1993$ & $\begin{array}{l}2010-2015 \\
\text { (this study) }\end{array}$ \\
\hline $\begin{array}{l}\text { Anacamptis } \\
\text { coriophora }\end{array}$ & $\begin{array}{l}\text { Food \& strengthening } \\
\text { (Landerer, 1850) }\end{array}$ & None \\
\hline Anacamptis morio & $\begin{array}{l}\text { Food \& strengthening } \\
\text { (Landerer, 1850) }\end{array}$ & None \\
\hline $\begin{array}{l}\text { Anacamptis } \\
\text { papilionacea }\end{array}$ & $\begin{array}{l}\text { Food \& strengthening } \\
\text { (Landerer, 1850) }\end{array}$ & None \\
\hline $\begin{array}{l}\text { Anacamptis } \\
\text { pyramidalis }\end{array}$ & $\begin{array}{l}\text { Not specified (Lazarides, } \\
1986 \text { ) }\end{array}$ & $\begin{array}{l}\text { Beverage, } \\
\text { medicinal }\end{array}$ \\
\hline $\begin{array}{l}\text { Dactylorhiza } \\
\text { sambucina }\end{array}$ & None & $\begin{array}{l}\text { Beverage, } \\
\text { medicinal }\end{array}$ \\
\hline $\begin{array}{l}\text { Dactylorhiza } \\
\text { saccifera }\end{array}$ & None & $\begin{array}{l}\text { Beverage, } \\
\text { medicinal }\end{array}$ \\
\hline Ophrys spp. & $\begin{array}{l}\text { Medicinal (Vokou et al., } \\
\text { 1993) }\end{array}$ & None \\
\hline $\begin{array}{l}\text { Orchis } \\
\text { anthropophora }\end{array}$ & $\begin{array}{l}\text { Food \& strengthening } \\
\text { (Landerer, 1850) }\end{array}$ & None \\
\hline Orchis italica & $\begin{array}{l}\text { Food \& strengthening } \\
\text { (Landerer, 1850) }\end{array}$ & None \\
\hline Orchis mascula & $\begin{array}{l}\text { Food \& strengthening } \\
\text { (Landerer, 1850) }\end{array}$ & $\begin{array}{l}\text { Beverage, } \\
\text { medicinal }\end{array}$ \\
\hline Orchis militaris & $\begin{array}{l}\text { Not specified (Lazarides, } \\
1986 \text { ) }\end{array}$ & $\begin{array}{l}\text { Beverage, } \\
\text { medicinal }\end{array}$ \\
\hline Orchis provincialis & $\begin{array}{l}\text { Not specified (Lazarides, } \\
1986 \text { ) }\end{array}$ & $\begin{array}{l}\text { Beverage, } \\
\text { medicinal }\end{array}$ \\
\hline Orchis simia & None & $\begin{array}{l}\text { Beverage, } \\
\text { medicinal }\end{array}$ \\
\hline Orchis spp. & $\begin{array}{l}\text { Medicinal (Vokou et al., } \\
\text { 1993) }\end{array}$ & None \\
\hline
\end{tabular}

A key informant collected salep and sold it as a hot beverage during the winter months from a mobile stall in one of the ski areas in northern Greece. He estimated to use up to $750 \mathrm{~g}$ of ground salep per day to prepare 150 cups of hot salep beverage. The street vendors that we interviewed in Thessaloniki obtained dried, unground orchid tubers from middlemen in the trade of tubers from neighbouring Albania and Turkey. One of the vendors estimated using c. $25 \mathrm{~kg}$ of raw tubers per year in the production of hot salep beverage. The owner of a company specializing in the trade of local herbs and spices in Kozani had started trading salep only 7 years previously; he reported buying tubers from collectors in northern Greece, most of whom did not reveal their exact harvesting areas or locations. He estimated he had sold $200 \mathrm{~kg}$ of ground salep in 2012 and had paid collectors EUR 55-85 per kg for salep of Greek origin. $\mathrm{He}$ also noted an increase in demand year by year as the popularity of salep drinks increases. The owner of a herb and spice shop in downtown Thessaloniki informed us that the unpackaged salep he sells is collected in the Grammos mountains. He also reported selling only salep 

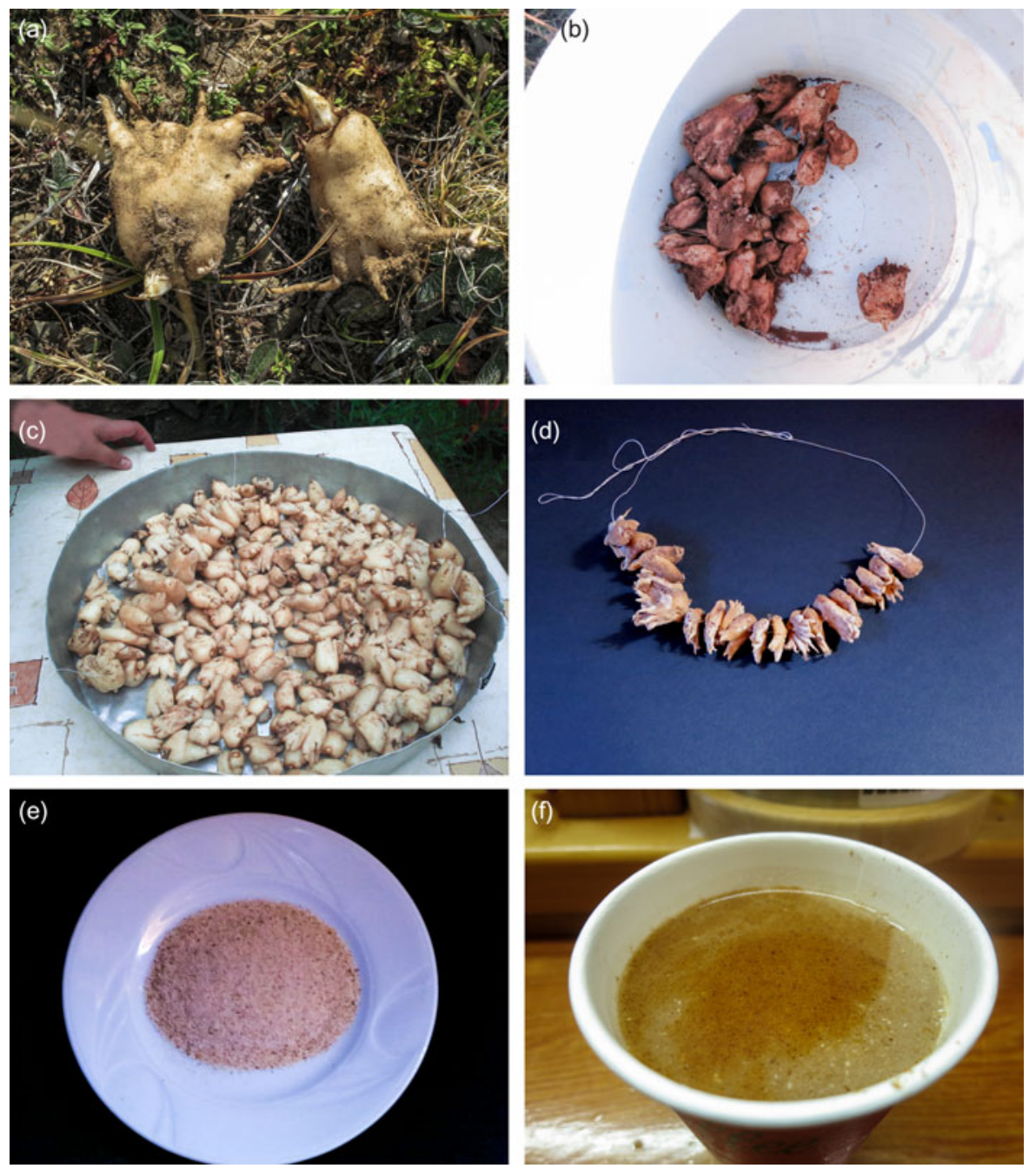

Plate 1 Freshly collected tubers of Dactylorhiza sambucina from Zagorohoria (a) and Grevena (b); tubers of Dactylorhiza sambucina left to dry in Distrato (c); dried tubers for home use in a village in Grevena (d); ground salep in Distrato (e); and salep beverage for sale near a ski centre (f). harvested in Greece. Another company operating in the Greek domestic market sold ground salep mixed with corn starch and common spices, such as cinnamon, nutmeg and cloves. The packaging labels claimed that the salep was sourced from cultivated stock but we found no evidence for this. Based on information from informants we established that packaged salep may retail for up to EUR 143 per $\mathrm{kg}$ (based on a price of EUR $5-10$ for $60-70 \mathrm{~g}$ ).

The renewed popularity of salep is driven by consumer demand for traditional, organic and alternative food but consumers may not realize that traditional products can contain threatened wildlife. Landerer (1850) reported various salep species in the genera Anacamptis and Orchis, and reported that these occurred abundantly in Thessaly and Macedonia (Table 1). Vokou et al. (1993) reported the use of species of Ophrys and Orchis but mentioned no specific species of either genus. We discovered that seven species of three genera, Anacamptis, Dactylorhiza and Orchis, are used for the production of salep in northern Greece. The use of Dactylorhiza has not been reported previously in Greece, but it has been reported in Turkey (Kasparek \&
Grimm, 1999) and Iran (Ghorbani et al., 2014b), probably following overharvesting of the more desired genera Anacamptis and Orchis. Several species used in the past for salep production have become more rare in recent decades as a result of overharvesting. Several species of Ophrys have been added to the IUCN Red List (IUCN, 2013), possibly spurred by the use of additional species for salep production.

The collectors that we followed in the field left only a few smaller plants standing during collecting. In most cases there were holes in the ground, indicating that other collectors had already been to the area. In the 1850 s Landerer reported that the main harvesting season was the autumn, when the meadows and terraces were tilled, and the orchids had set seed and wilted. He also wrote that the tubers were selected by size, and many of the smaller tubers were replanted to promote regrowth. Sumpter et al. (2004) provided experimental evidence of the regenerative capacity of old orchid tubers. We recorded neither dispersal of young tubers nor replanting of old tubers. 
The annual harvests of thousands of $50 \mathrm{~kg}$ (centner) units of salep reported in the 1850 (Landerer, 1850) no longer occur, as orchids have become rare and remaining populations have lost resilience to such harvesting pressure (Petrou et al., 2011). The number of fresh orchid tubers harvested per $\mathrm{kg}$ of salep is estimated to be 220-250 (Ghorbani et al., 2014a). In Iran, where an orchid collection boom is threatening wild populations, an estimated 6 million tubers are harvested annually (Ghorbani et al., 2014a).

The increasing popularity of traditional, organic food provides much-needed opportunities for an alternative source of income for the people of north-western Greece. Salep can be produced sustainably, and the species of orchids that yield the best salep (Orchis mascula, Orchis militaris and Anacamptis morio; Hawkes, 1944) can be cultivated (Seaton \& Ramsay, 2005). Local propagation and sustainable cultivation alleviate harvesting pressure on wild orchids but subsequent trade poses challenges in the context of national and international legislation, such as CITES (Entwistle et al., 2002; McGough et al., 2014). Our survey revealed ongoing and increasing collection of wild orchids, and we are now informing local authorities of the implications of commercialization of salep products. We are also working with collectors who expressed an interest in piloting small-scale cultivation, and companies interested in sustainably cultivated salep, to provide expertise on seed collecting, propagation and cultivation. Subsequent questions about commercialization within the framework of national legislation have not yet been addressed.

\section{Acknowledgements}

We thank all informants for sharing their knowledge. In addition we acknowledge the staff of the Lazarides Folklore Museum in Koukouli for their assistance, Erik-Jan Bosch for creating Fig. 1, and Socrates Tsouplakis for creating Fig. 2.

\section{References}

BerLiocchi, L. (1996) Il fiore degli dei l'orchidea dal mito alla storia. Stampa Alternativa, Rome, Italy.

Bulpitt, C.J. (2005) The uses and misuses of orchids in medicine. QJM, 98, 625-631.

Davenport, T.R.B. \& Ndangalasi, H.J. (2003) An escalating trade in orchid tubers across Tanzania's Southern Highlands: assessment, dynamics and conservation implications. Oryx, 37, 55-61.

Delforge, P. (2006) Orchids of Europe, North Africa and the Middle East. A\&C Black, London, UK.
Entwistle, A., Atay, S., Byfield, A. \& Oldfield, S. (2002) Alternatives for the bulb trade from Turkey: a case study of indigenous bulb propagation. Oryx, 36, 333-341.

Ghorbani, A., Gravendeel, B., Na Ghibi, F. \& de Boer, H.J. (2014a) Wild orchid tuber collection in Iran: a wake-up call for conservation. Biodiversity and Conservation, 23, 2749-2760.

Ghorbani, A., Gravendeel, B., Zarre, S. \& de Boer, H.J. (2014b) Illegal wild collection and international trade of CITES-listed terrestrial orchid tubers in Iran. TRAFFIC Bulletin, 26, 52-58.

Haw kes, A.D. (1944) Economic importance of the Orchidaceae. II. American Orchid Society Bulletin, 13, 56-58.

IUCN (2013) IUCN Red List of Threatened Species v. 2014.3. Http:// www.iucnredlist.org/ [accessed 6 March 2015].

Kasparek, M. \& Grimm, U. (1999) European trade in Turkish salep with special reference to Germany. Economic Botany, 53, 396-406.

Landerer, X. (1850) Naturgeschichte und Pharmakognosie. Beiträge zur Pharmakognosie. Ueber Salep und die Salepisiden. Archiv der Pharmazie, 112, 177-180.

Lazarides, K. (1986) Botanical and Folk Elements of the Flora of My Village Koukouli, Zagori and of the Vikos Gorge. Ioannina, Greece.

McGough, H.N., Kikodze, D., Wilford, R., Garrett, L., Deisadze, G., Jaworska, N. \& Smith, M.J. (2014) Assessing non-detrimental trade for a CITES Appendix II-listed plant species: the status of wild and cultivated Galanthus woronowii in Georgia. Oryx, 48, 345-353.

Petrou, N., Petrou, M. \& Giannakoulias, M. (2011) Orchids of Greece. Koan Publishing House, Athens, Greece.

Seaton, P. \& Ramsay, M. (2005) Growing Orchids from Seed. Royal Botanic Gardens, Kew, London, UK.

SeziK, E. (2002) Turkish orchids and salep. Acta Pharmaceutica Turcica, 44, 151-157.

SEZIK, E. (2006) Destroying of Ophrys species to obtain salep in Turkey. Journal Europäischer Orchideen, 38, 290.

STARIN, D. (2012) Salepi extinction, salepi survival: how a change in ingredients could help safeguard orchids. Orchids, 81, 490-494.

Sumpter, J.P., D’Ayala, R., Parfitt, A.J., Pratt, P. \& Raper, C. (2004) The current status of military (Orchis militaris) and monkey (Orchis simia) orchids in the Chilterns. Watsonia, 25, 175-184.

Tamer, C.E., Karaman, B. \& Copur, O.U. (2006) A traditional Turkish beverage: salep. Food Reviews International, 22, 43-50.

Veldman, S., Otieno, J.N., van Andel, T., Gravendeel, B. \& de BOER, H.J. (2014) Efforts urged to tackle thriving illegal orchid trade in Tanzania and Zambia for chikanda production. TRAFFIC Bulletin, 26, 47-50.

Vokou, D., Katradi, K. \& Kokkini, S. (1993) Ethnobotanical survey of Zagori (Epirus, Greece), a renowned centre of folk medicine in the past. Journal of Ethnopharmacology, 39, 187-196.

\section{Biographical sketches}

ANNA KREZIOU is a biologist and teacher in Thessaloniki, and is conducting research on trade and identification of orchids. HUGO DE B OER combines ethnobotany and DNA barcoding to elucidate species identity and diversity of wild-harvested plants in international trade. BARBARA GRAVENDEEL is an orchidologist and molecular biologist specialized in DNA barcoding and wildlife forensics. 